\title{
The toll-like receptor 4 agonist MRP8/14 protein complex (calprotectin) in autoinflammation: potential biomarker in chronic nonbacterial osteomyelitis - a case report
}

\author{
Juergen Brunner \\ From 21st European Pediatric Rheumatology (PReS) Congress \\ Belgrade, Serbia. 17-21 September 2014
}

\section{Introduction}

The cytoplasmic S100 proteins derived from cells of myeloid origin. Calprotectin (MRP8/14 protein complex) might be a biomarker either for autoinflammation and autoimmunopathy. Since autoinflammatory diseases might be a diagnostic challenge calprotectin may be helpful in the diagnosis of autoinflammatory diseases. Chronic nonbacterial osteomyelitis $(\mathrm{CNO})$ is an autoinflammatory, noninfectious disease. CNO describes a wide spectrum from a monofocal bone lesion to the chronic recurring multifocal osteomyelitis (CRMO). Laboratory and histopathological findings are nonspecific. In some patients systemic inflammatory signs such as elevated acute phase proteins cannot be found.

\section{Objectives}

To test the ability of Calprotectin (MRP8/14 protein complex) serum concentrations to monitor disease activity in patients with $\mathrm{CNO}$.

\section{Methods}

Serum concentrations of Calprotectin (MRP8/14 protein complex) in a patient with $\mathrm{CNO}$ were determined by a sandwich ELISA.

\section{Results}

Calprotectin (MRP8/14) level were raised heralding active disease when acute phase proteins $(\mathrm{CrP}$, erythrocyte sedimentation rate). The calprotectin level was $7872,7 \mathrm{ng} / \mathrm{ml}$ (normal range $0-3000 \mathrm{ng} / \mathrm{ml}$ ).

\footnotetext{
Pediatrics, Medical University Innsbruck, Innsbruck, Austria
}

\section{Conclusion}

Calprotectin (MRP8/14) serum concentrations correlate closely with disease activity and may herald a flare before clinical manifestation. Therefore MRP8/14 serum concentrations are a biomarker indicating disease activity in $\mathrm{CNO}$ patients.

\section{Disclosure of interest}

None declared.

Published: 17 September 2014

doi:10.1186/1546-0096-12-S1-P255

Cite this article as: Brunner: The toll-like receptor 4 agonist MRP8/14 protein complex (calprotectin) in autoinflammation: potential biomarker in chronic nonbacterial osteomyelitis - a case report. Pediatric

Rheumatology 2014 12(Suppl 1):P255.
Submit your next manuscript to BioMed Central and take full advantage of:

- Convenient online submission

- Thorough peer review

- No space constraints or color figure charges

- Immediate publication on acceptance

- Inclusion in PubMed, CAS, Scopus and Google Scholar

- Research which is freely available for redistribution 